\title{
Uitstelgedrag in outplacementsituaties ${ }^{*}$
}

\author{
Monique V.E. Leenders \& Jua B.P. Sanders**
}

In deze studie is bij werknemers in een outplacementsituatie de relatie onderzocht tussen een aantal variabelen (locus of control, professionele zelfverzekerdheid, sollicitatie-self-efficacy, prestatiemotivatie en positieve faalangst) en uitstelgedrag. In totaal vulden 134 werknemers die hun baan verloren als gevolg van een bedrijfssluiting of een reorganisatie, werkzaam bij verschillende organisaties, de vragenlijst in. Het blijkt dat degenen met een externe locus of control en zij die lager scoren op prestatiemotivatie, meer uitstelgedrag vertonen. Werknemers die regelmatig uitstellen, bleken echter na een begeleidingsperiode van vier maanden niet minder vaak een baan te hebben dan werknemers die minder uitstellen. Mogelijk zijn er andere factoren mede van invloed op de kans om ander werk te vinden, bijvoorbeeld de vraag naar specifieke vakkrachten op de arbeidsmarkt.

\section{Introductie}

Door de economische crisis verliezen op dit moment veel werknemers hun baan. Om te voorkomen dat zij (langdurig) werkloos raken, wordt veelal outplacement ingezet om hen van werk naar werk te begeleiden. In deze trajecten worden werknemers met behulp van professionele ondersteuning begeleid in het aanleren van sollicitatievaardigheden om werkloosheid te voorkomen. Voor veel mensen is solliciteren echter een moeilijk en zwaar proces. Een probleem dat in de praktijk bij de begeleiding van kandidaten zichtbaar wordt, is het uitstellen en niet nakomen van gemaakte afspraken of het achterwege laten van noodzakelijke acties om een andere baan te vinden, terwijl men wel voldoende vertrouwen heeft in de eigen competenties op het werk. Onderzoek naar dit onderwerp is actueel en belangrijk, omdat werknemers in toenemende mate, al dan niet gedwongen, gedurende hun loopbaan meerdere keren moeten solliciteren.

In Europa vindt er (en dus ook in Nederland en België) sinds de jaren negentig een sterke saneringsgolf plaats. Herstructureringen, fusies, overnames, 'downsizing' en bedrijfssluitingen beheersen het economische nieuws (De Witte, Van Hoof \& Vos, 2007). Ook is er door de globalisering sprake van een intensivering van het werk, meer reorganisaties en een toenemende mate van werkonzekerheid (Houtman \& Van den Bossche, 2010). In 2009 en 2010 werden in Nederland respectievelijk 105.000 en 122.000 mensen gedwongen ontslagen. Eind 2011 waren

* De auteurs zijn prof. dr. Bram Buunk, prof. dr. Kène Henkens en twee anonieme reviewers dankbaar voor hun opmerkingen bij eerdere versies van dit artikel.

** Monique V.E. Leenders is als psycholoog werkzaam bij loopbaanadviesbureau Thaeles in Malden. Correspondentieadres: Zwerfkei 7, 6581 HN Malden, e-mail: monique.leenders@thaeles.nl. Jua B.P. Sanders heeft de masteropleiding Behavioral Science aan de Radboud Universiteit Nijmegen afgerond. 
er gemiddeld 465.000 mensen werkloos (CBS, 2012) en eind 2012 waren dit er 507.000 (CBS, 2013a). In het eerste kwartaal van 2013 kwamen er gemiddeld 24.000 werklozen per maand bij (CBS, 2013b).

Uit gegevens van het Sociaal en Cultureel Planbureau (Vlasblom, Josten \& De Voogd-Hamelink, 2013) blijkt verder dat er een verschuiving zichtbaar is in de interne arbeidsmobiliteit. Werknemers wisselen binnen de eigen organisatie vaker van baan dan voorheen. In vergelijking met de periode 1992-1994 is tussen 2008 en 2010 deze mobiliteit bijna verdubbeld naar 18\%. Bovendien blijkt dat in 2008 ongeveer $17 \%$ van de werknemers een tijdelijke aanstelling had, waardoor ze eveneens vaker (moeten) solliciteren.

In de wetenschappelijke literatuur wordt relatief weinig aandacht besteed aan uitstelgedrag bij volwassenen en nog minder aan uitstel in relatie tot het solliciteren. Veel onderzoek richt zich op studenten, mede omdat verondersteld wordt dat met het ouder worden de neiging tot uitstelgedrag minder wordt (Steel, 2007; Van Eerde, 2003). Uitbreiding van onderzoek over uitstelgedrag naar andere domeinen, zoals in outplacementsituaties, kan onze kennis en ons begrip hierover verbreden en loopbaanprofessionals helpen op het individu toegepaste interventies in te zetten.

Uitstelgedrag is al langer een erkend probleem, maar de prevalentie ervan lijkt in de westerse maatschappij wel toe te nemen (Steel, 2007). Volgens Harriott en Ferrari (1996) vertoont 20\% van de volwassenen uitstelgedrag bij de uitvoering van dagelijkse taken, zoals het betalen van rekeningen. Voor studenten liggen de percentages tussen de 70 en 95\%. Ferrari, Johnson en McCown (1995) veronderstellen dat dit verschil te maken heeft met verschillende vormen van uitstelgedrag, waarbij het gedrag bij studenten een voorbeeld is van situatie-specifiek uitstellen van taken (namelijk het uitstellen van studietaken) en het gedrag op latere leeftijd eerder chronisch uitstelgedrag is, passend bij de persoonlijkheid. Dit sluit niet uit dat in specifieke situaties, analoog aan die bij studenten, ook bij ouderen uitstelgedrag optreedt.

Uitstelgedrag wordt in de Engelse literatuur aangeduid met het oorspronkelijk uit het Latijn afkomstige woord procrastination, dat letterlijk vertaald 'op morgen schuiven' betekent. Het is de neiging datgene uit te stellen wat eigenlijk nodig is om een bepaald doel te bereiken (Lay, 1986). Volgens Burka en Yuen (1983) gaat het bij uitstelgedrag om het gedrag van uitstellen. Iedereen stelt weleens uit, maar wat uitstelgedrag tot een probleem maakt, is de mate waarin het gedrag door iemand zelf als hinderlijk/lastig wordt ervaren. De gevolgen ervan kunnen zowel hun weerslag hebben op de persoon zelf als op zijn of haar omgeving, zoals het verlies van een baan of een echtscheiding. Uitstelgedrag kan op korte termijn voordelig zijn, maar op lange termijn is het eerder nadelig (Steel, 2007; Van Eerde, 2003) en kan het schadelijk zijn voor het welzijn en de gezondheid van het individu (Wohl, Pychyl \& Bennet, 2010).

Er bestaan verschillende verklaringen voor uitstelgedrag: mensen die uitstelgedrag vertonen, zijn vaak minder betrokken bij onplezierige of moeilijke taken dan zij die dit gedrag niet vertonen, terwijl deze taken niettemin noodzakelijk zijn voor het bereiken van een bepaald doel (Lay, 1986). Uitstelgedrag kan angst om te falen of angst voor succes weerspiegelen of kan zelfs een afgeleide zijn van de 
behoefte tot rebellie (Burka \& Yuen, 1983). Het is bovendien irrationeel, omdat men weet dat het uiteindelijk niet in het eigen voordeel is (Steel, 2007).

Uitstelgedrag wordt gezien als een onvermogen tot zelfregulering (Baumeister \& Heatherthon, 1996). Zelfregulering houdt in: (1) het stellen van doelen, (2) het monitoren van het eigen gedrag in relatie tot deze doelen, en (3) het veranderen van de eigen houding en de omgeving om deze doelen te kunnen bereiken (Carver \& Scheier, 2000). Deze zelfregulering faalt als men niet in staat is deze activiteiten te coördineren of succesvol uit te voeren (Renn, Allen, Fedor \& Davis, 2005). Mensen die uitstelgedrag vertonen, lijken meer moeite te hebben om deze verschillende componenten te hanteren dan degenen zonder uitstelgedrag.

Het doel van dit onderzoek is na te gaan welke individuele verschilvariabelen samenhangen met uitstelgedrag bij volwassenen in een outplacementsituatie. We kijken daarbij in de eerste plaats naar de rol van een persoonskenmerk (locus of control), zelf-evaluatie-variabelen (professionele zelfverzekerdheid en sollicitatieself-efficacy), een tweetal variabelen die motivatie representeren (prestatiemotivatie en positieve faalangst) en hun relatie met uitstelgedrag. Vervolgens onderzoeken we de relatie tussen uitstelgedrag en het vinden van een baan in de context van een outplacementsituatie.

\section{Literatuuroverzicht}

In het onderzoek naar de relatie tussen persoonlijkheid en werktevredenheid zijn Judge, Locke en Durham (1997) uitgegaan van een higher order construct, dat zij de term core-self-evaluations hebben gegeven, een breder persoonskenmerk bestaande uit een viertal specifiekere kenmerken, waaronder zelfvertrouwen, neuroticisme, locus of control en self-efficacy in het algemeen. Deze indeling is uitgangspunt geweest voor de verschillende variabelen in ons onderzoek. Naast locus of control hebben we meer taak-specifieke vormen van self-efficacy onderzocht, namelijk professionele zelfverzekerdheid en het vertrouwen in de eigen vaardigheden als het gaat om het solliciteren (sollicitatie-self-efficacy).

\subsection{Locus of control}

De onderzochte rol van verschillende persoonskenmerken in relatie tot uitstelgedrag heeft zich tot nu toe grotendeels gericht op de dimensies van de Big Five. In de literatuur wordt relatief weinig aandacht besteed aan andere kenmerken, zoals locus of control (LOC). Locus of control betreft de mate waarin mensen het gevoel hebben dat ze controle hebben over hun eigen lot (Ng, Sorensen \& Eby, 2006). Rotter (1966) maakte een onderscheid tussen mensen met een interne LOC en mensen met een externe LOC. Degenen met een interne LOC geloven dat ze de baas zijn over hun lot en dus hun eigen toekomst kunnen beïnvloeden. Zij ervaren vaak een sterke relatie tussen hun acties en consequenties (Rotter, 1996) en schrijven persoonlijke successen toe aan hun eigen inspanningen. Als mensen met een interne LOC falen, schrijven zij de oorzaken hiervan toe aan het onvoldoende verrichten van inspanningen (Miner, 2002). Mensen met een externe LOC daarentegen geloven dat ze geen invloed kunnen uitoefenen op hun lot. Zij 
schrijven persoonlijke successen doorgaans toe aan geluk of toeval en falen aan andere (externe) factoren (Grimes, Millea \& Woodruff, 2004; Miner, 2002). Rothblum, Solomon en Murakami (1986) vonden in hun onderzoek dat studenten met een externe locus of control meer uitstelgedrag vertoonden dan degenen met een interne locus of control. Dit betekent dat men zich minder inspant en meer uitstelgedrag vertoont, omdat men minder persoonlijke controle ervaart over de uitkomst van een situatie (Lowman, 1993). Onze eerste hypothese is hierop gebaseerd.

Hypothese 1: Werknemers met een externe locus of control vertonen meer uitstelgedrag dan werknemers met een interne locus of control.

\subsection{Professionele zelfuerzekerdheid en sollicitatie-self-efficacy}

Self-efficacy in het algemeen verwijst naar het vertrouwen dat iemand in zichzelf heeft om taken die gedaan moeten worden af te maken, om gedrag vol te houden en de kwaliteit van de prestatie te verbeteren om succesvol een doel te kunnen bereiken (Bandura, 1977; Van Ryn \& Vinokur, 1992). Bekend is dat er een relatie is tussen self-efficacy en uitstelgedrag (Steel, 2010). Professionele zelfverzekerdheid en sollicitatie-self-efficacy zijn meer taak-specifieke vormen van self-efficacy en hebben een smallere focus (Caska, 1998).

Professionele zelfverzekerdheid verwijst naar de mate waarin iemand vertrouwen heeft in de eigen kwaliteiten. Verondersteld wordt dat uitstelgedrag minder vaak voorkomt bij taken waarvan iemand weet dat hij of zij deze beheerst (Lay \& Brokenshire, 1997; Pychyl, Lee, Thibodeau \& Blunt, 2000; Senécal \& Guay, 2000; Steel, 2010; Van Eerde, 2000). Watson (2001) is van mening dat mogelijk in de perceptie van weerzin tegen taken een leeftijdgerelateerde verandering plaatsvindt: naarmate men ouder wordt, heeft men een groter repertoire opgebouwd van (werk)ervaringen uit het verleden. Verondersteld kan worden dat werknemers gedurende hun arbeidzame leven ervaring in de eigen competenties op het werk hebben opgebouwd en hier dan ook voldoende vertrouwen in hebben. Dit leidt tot onze volgende hypothese.

Hypothese 2a: Professionele zelfverzekerdheid heeft een negatieve relatie met uitstelgedrag. Naarmate werknemers meer professionele zelfverzekerdheid ervaren, vertonen ze minder uitstelgedrag.

Sollicitatie-self-efficacy is de overtuiging dat men succesvol specifiek sollicitatiezoekgedrag kan uitvoeren en hierdoor (ander) werk weet te verwerven (Saks \& Ashforth, 1999). Mensen die hier minder vertrouwen in hebben, kunnen het solliciteren als veeleisend of bedreigend ervaren, waardoor gedragsproblemen zoals uitstelgedrag kunnen ontstaan (Cole, 2006). Specifiek onderzoek naar de relatie tussen sollicitatie-self-efficacy en uitstelgedrag is er nauwelijks. Wel zijn er verscheidene onderzoeken uitgevoerd naar de relatie tussen sollicitatie-self-efficacy en het wel of niet vinden van een baan (Kanfer, Wanberg \& Krantowitz, 2001; Zikic \& Saks, 2009). Naarmate men meer vertrouwen had in de eigen sollicitatievaardigheden, vond men vaker een baan. In hun onderzoek naar sollicitatieintenties en sollicitatiegedrag vonden Lay en Brokenshire (1997) dat werklozen die hun competenties om sollicitatieactiviteiten te ondernemen lager inschatten, 
over een periode van twee weken meer uitstelgedrag vertoonden dan degenen die zichzelf meer competent achtten. Ook had de eerste groep minder de intentie hiermee te beginnen. Hieruit vloeit de volgende hypothese voort.

Hypothese 2b: Werknemers die meer self-efficacy bij het solliciteren ervaren, vertonen minder uitstelgedrag dan zij die minder sollicitatie-self-efficacy ervaren.

\subsection{Prestatiemotivatie en positieve faalangst}

Bij uitstelgedrag speelt ook motivatie een belangrijke rol (Van Eerde, 2000; 2003). Motivatie kan worden gezien als de drijvende kracht achter allerlei acties van individuen (Rabideau, 2005). Prestatiemotivatie is de mate waarin iemand gericht is op het behalen van prestaties (McClelland, Atkinson, Clark \& Lowell, 1953) en de wil om goed te presteren (Hermans, 1970). Mensen met een hoge prestatiemotivatie stellen doorgaans hogere eisen aan zichzelf (McClelland et al., 1953) en lijken meer vanuit eigenbelang te genieten van werk dan mensen met een lagere prestatiemotivatie (Steel, 2007). In een meta-analyse vond deze auteur een effect van $r=-.35$ tussen prestatiemotivatie en uitstelgedrag. Senécal en Guay (2000) vonden bij studenten dat uitstelgedrag de relatie tussen self-determined sollicitatiezoekgedrag (= de mate waarin iemand van binnenuit gemotiveerd is naar werk te zoeken) en gevoelens van hopeloosheid medieerde. Motivatie had een positieve relatie met uitstelgedrag en meer uitstelgedrag leidde over een periode van zes maanden tot meer gevoelens van hopeloosheid. Hieruit volgt de volgende hypothese.

Hypothese 3a: Prestatiemotivatie heeft een negatieve relatie met uitstelgedrag. Naarmate men meer gericht is op het behalen van successen, vertoont men minder uitstelgedrag.

Positieve faalangst wordt actief in die situaties die relatief ongestructureerd zijn (weinig overzicht, complex, nieuw en onbekend) en die op enigerlei wijze een voor de persoon belangrijk karakter hebben. In dergelijke situaties kan positieve faalangst iemand in een optimale spanningstoestand brengen, waardoor deze beter gaat functioneren dan onder normale omstandigheden het geval is (Hermans, 1970). Werknemers in een outplacementsituatie hebben gedurende de periode waarin zij moeten solliciteren, in sterke mate te maken met een onbekend en ongestructureerd proces, omdat lang niet altijd helder is aan welke eisen men moet voldoen. Een dergelijke situatie kan gevoelens van angst oproepen. Dit kan mensen ertoe bewegen zich extra goed voor te bereiden op een moeilijke taak of op een situatie waar men tegenop ziet. Op basis hiervan kan men verwachten dat mensen met positieve faalangst minder snel geneigd zijn activiteiten uit te stellen. We toetsen daarom de volgende hypothese.

Hypothese 3b: Positieve faalangst heeft een negatieve relatie met uitstelgedrag.

\subsection{Uitstelgedrag en het vinden van een baan}

Kanfer et al. (2001) definiëren sollicitatiezoekgedrag als het resultaat van een dynamisch en doelgericht proces dat begint met de identificatie van een doel. Enerzijds is solliciteren een langdurig en onzeker proces omdat lang niet altijd helder is aan welke eisen moet worden voldaan. Anderzijds is solliciteren eenvou- 
dig, in die zin dat het doel ervan helder en concreet is: het vinden van een nieuwe baan (Knaus, Klarreich, Grieger \& Knaus, 2010). Om dit te kunnen realiseren is een bepaalde mate van zelfregulering noodzakelijk. Deze zelfregulatie-strategieën kunnen uiteenlopen van het verrichten van bepaalde inspanningen, tot volharding en emotionele controle, ondanks teleurstellingen en afwijzingen waarmee men te maken kan krijgen in sollicitatieprocedures. Men moet andere strategieën kunnen bedenken als duidelijk wordt dat bepaalde activiteiten niet tot het gewenste resultaat leiden (Van Hooft \& Noordzij, 2009). Wil men het succes van het vinden van ander werk vergroten, dan moeten er doorgaans verschillende (nieuwe) vaardigheden worden aangeleerd. Er wordt bijvoorbeeld verwacht dat men zichzelf kan presenteren in een sollicitatiegesprek, een eigenschap waarover niet iedereen in even sterke mate beschikt. Dit kan verklaren waarom uitstelgedrag in outplacementsituaties zichtbaar wordt.

Er is nauwelijks onderzoek gedaan naar de relatie tussen uitstelgedrag en het vinden van een andere baan. Wel is bekend dat mensen die uitstelgedrag vertonen, vaker werkloos zijn dan zij die dat niet doen (Steel, 2011). Wanberg, Zhu en Van Hooft (2010) deden onderzoek bij werklozen naar de dynamiek van werkzoekgedrag. Zij onderzochten action-state orientation als een index van zelfregulering. Action-state orientation bestaat onder andere uit de vaardigheid acties te initiëren en prioriteiten te stellen bij taken, kenmerken die overeenkomen met het tegenovergestelde van uitstelgedrag. Naarmate deze dimensie bij werkzoekenden meer aanwezig was, zocht men gedurende een periode van drie weken actiever naar werk. Actiever zoeken naar werk vergroot de kans om bij geschikte vacatures of interessante werkgevers uit te komen en daarmee ook de kans om een andere baan te vinden.

De specifieke relatie tussen locus of control, verschillende zelf-evaluatie- en motivatie-variabelen, uitstelgedrag en het vinden van een baan is echter onduidelijk. Enerzijds kunnen deze variabelen van invloed zijn op het vinden van een baan, in die zin dat mensen die meer over deze eigenschappen beschikken, hierin eerder succesvol zullen zijn dan mensen die minder over deze eigenschappen bezitten, bijvoorbeeld omdat men erop vertrouwt het sollicitatieproces goed te kunnen doorlopen. Anderzijds is het denkbaar dat iemand die weinig vertrouwen heeft in de eigen sollicitatievaardigheden, last heeft van uitstelgedrag en er daardoor langer over doet om ander werk te vinden. Uitstelgedrag zou dan de relatie tussen de verschillende variabelen in ons onderzoek en het vinden van een baan mediëren (Baron \& Kenny, 1986), bijvoorbeeld door weinig tijd te besteden aan het vinden van (geschikte) vacatures en/of vlak voor het verstrijken van de deadline een brief schrijven die kwalitatief minder is dan wanneer deze ruim op tijd geschreven was. In figuur 1 worden deze verschillende relaties weergegeven.

Om de mediërende rol van uitstelgedrag te kunnen onderzoeken moeten de verschillende variabelen met elkaar samenhangen. Er moet dus een relatie zijn tussen uitstelgedrag en het vinden van een baan, een relatie tussen de verschillende variabelen en uitstelgedrag en tussen deze variabelen en het vinden van een baan (Baron \& Kenny, 1986). Hieruit volgen onze laatste hypotheses.

Hypothese 4a: Werknemers die meer uitstelgedrag vertonen, vinden minder vaak een andere baan dan zij die minder uitstellen. 


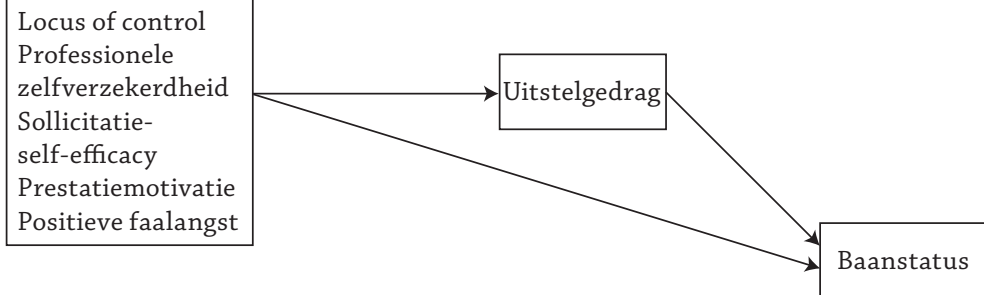

Figuur 1 De relatie tussen de verschillende variabelen en baanstatus en de mediërende rol van uitstelgedrag tussen deze variabelen en baanstatus

Hypothese 4b: Mensen met een interne locus of control, een grotere mate van professionele zelfverzekerdheid en sollicitatie-self-efficacy, een sterkere prestatiemotivatie en meer positieve faalangst vinden vaker een baan dan mensen die in mindere mate over deze eigenschappen beschikken.

Hypothese 4c: Uitstelgedrag medieert de relatie tussen de verschillende variabelen (locus of control, professionele zelfverzekerdheid, sollicitatie-self-efficacy, prestatiemotivatie en positieve faalangst) en het vinden van een baan.

\subsection{Controlevariabelen}

De controlevariabelen in dit onderzoek waren: leeftijd (gemeten als een continue variabele); geslacht (gemeten als dummyvariabele: $\operatorname{man}=0$, vrouw $=1$ ) en opleiding (gemeten als twee dummyvariabelen met als referentiecategorie lagere school: lagere school = $0, \mathrm{mbo}=1$ en lagere school $=0$, hbo/wo $=1)$. Er is al redelijk veel onderzoek gedaan naar de relatie tussen de verschillende persoonlijkheidseigenschappen van de Big Five en uitstelgedrag. Emotionele stabiliteit $(M=3.66, S D=.58)$ en extraversie $(M=3.51, S D=.45)$ werden om die reden eveneens in ons onderzoek meegenomen als controlevariabelen (Hoekstra, Ormel \& Fruyt, 2007).

\section{Methode}

\subsection{Steekproef en gegevensverzameling}

Voor dit onderzoek zijn 225 werknemers benaderd die tussen 2009 en 2011 hun baan verloren wegens een reorganisatie of door een bedrijfssluiting en die vanuit de eigen organisatie een outplacementtraject kregen aangeboden om hen van werk naar werk te begeleiden. De participanten waren werkzaam in acht verschillende organisaties en kwamen uit zowel de profit- als de non-profitsector. Aan het onderzoek werkten uiteindelijk 134 werknemers mee.

Deelnemers werden via de mail benaderd met het verzoek aan het onderzoek deel te nemen. De werknemers konden vervolgens de vragenlijst digitaal invullen. $\mathrm{Na}$ twee weken is eenmalig nogmaals via de mail een herinnering verzonden. Naast 
demografische achtergrondkenmerken van de werknemers is informatie verzameld over locus of control, professionele zelfverzekerdheid, sollicitatie-self-efficacy, prestatiemotivatie, positieve faalangst en uitstelgedrag en het wel of niet vinden van een baan gedurende de periode van de begeleiding. Omdat voor één van de bedrijven een outplacementtraject van maximaal vier maanden was afgesproken, is deze termijn gekozen om te onderzoeken of kandidaten wel of geen baan hadden. Voor deze gegevens werd gebruikgemaakt van het cliëntenvolgsysteem van een loopbaanadviesbureau dat is gespecialiseerd in outplacementbegeleiding. In totaal heeft 59.5\%, d.w.z. 134 van de 225 benaderde werknemers, de vragenlijst ingevuld. De totale groep bestond uit 109 mannen (= 81\%) en 25 vrouwen (=19\%), van wie 36\% laag was opgeleid (ongeschoold/lbo), 41\% midden (mbo) en $23 \%$ hoog (hbo/wo). De gemiddelde leeftijd was 49 jaar ( $S D=7.6$ ).

\subsection{Meetmethoden en schalen}

Uitstelgedrag: Voor deze schaal is gebruikgemaakt van een verkorte versie (acht items) van de algemene Procrastination Scale van Lay (1986). Sommige items waren niet van toepassing voor deze onderzoeksgroep en werden om die reden niet meegenomen in de uiteindelijke vragenlijst. De items werden vertaald naar het Nederlands. De schaal bestond uit de volgende items: (1) 'Ik kom het vaak tegen dat ik taken uitvoer waarvan ik me dagen eerder al voorgenomen had deze uit te voeren', (2*) 'Normaal gesproken neem ik zo snel als mogelijk beslissingen', (3) 'Over het algemeen stel ik uit te beginnen aan werk dat ik moet doen', (4) 'Als deadlines op mij afkomen, verdoe ik meestal de tijd door andere dingen te doen', $\left(5^{*}\right)$ 'Ik heb een taak vaker eerder afgemaakt dan noodzakelijk is', (6*) 'Normaal gesproken maak ik alle dingen af die ik voor een dag gepland heb', (7) 'Ik zeg voortdurend "ik zal het morgen doen", en $\left(8^{*}\right)$ 'Ik houd normaal gesproken de aandacht bij alle taken die ik moet doen, voordat ik 's avonds ga zitten en me ontspan'. De antwoordmogelijkheden bestonden uit 1 = 'helemaal onjuist' tot 5 = 'helemaal juist'. Voor deze schaal werden de scores van vier items (de items 2, 5,6 en 8) omgekeerd. Een hoge score betekende veel uitstelgedrag $(M=2.28$, $S D=.55)$. Cronbach's $\alpha$ was .88.

Locus of control: Voor deze schaal werd gebruikgemaakt van een gevalideerde vragenlijst afkomstig van het IPIP (International Personality Item Pool). Deze pool is ontwikkeld om onderzoek naar persoonskenmerken voor wetenschappers meer toegankelijk te maken. Het IPIP is deels ontstaan op basis van 1.252 tot meer dan 2.000 bestaande items die persoonskenmerken meten. Ieder jaar worden hier nieuwe items aan toegevoegd. Ongeveer 750 items komen oorspronkelijk uit het Nederlands (Goldberg et al., 2006). In totaal bevatte de locus of control-schaal twintig items. Voorbeelden van deze items zijn: 'Ik geloof dat mijn succes eerder afhangt van mijn vaardigheid dan van geluk', 'Ik geloof dat de wereld gecontroleerd wordt door een paar machtige mensen' en 'Ik geloof dat sommige mensen voor het geluk geboren zijn'. De antwoordcategorie liep van 1 = 'helemaal oneens' tot 5 = 'helemaal eens'. De scores op sommige items werden omgekeerd zodat een hoge score op deze schaal een interne locus of control betekende $(M=3.85$, $S D=.43)$. Cronbach's $\alpha=.89$. 
Professionele zelfuerzekerdheid: Deze schaal bestond uit acht items en was afkomstig uit een Impuls en Drijfveren Scan (Construct, 2009). Voorbeelden van items zijn: 'Ik voel mij op mijn gemak in een discussie over welk onderwerp dan ook' en 'Ik zou mij zeker voelen wanneer ik aan mijn manager moest uitleggen hoe ik mijn werk doe'. De antwoordcategorieën liepen van 1 = 'helemaal niet van toepassing' tot 5 = 'heel erg van toepassing'. Een hoge score betekende een grote mate van professionele zelfverzekerdheid. Het gemiddelde op deze schaal was $M=3.48$ en de standaarddeviatie $S D=.68$. Cronbach's $\alpha$ was .88 (Bijlage A).

Sollicitatie-self-efficacy: Deze schaal is speciaal ontwikkeld voor dit onderzoek en omvatte twintig items. Voorbeelden van deze items zijn: 'Ik weet niet hoe ik het solliciteren moet aanpakken', 'Ik ben ervan overtuigd dat ik de baan krijg die ik ook hebben wil' en 'Of ik ander werk vind heb ik zelf niet in de hand'. De antwoordcategorie liep van 1 'helemaal oneens' tot 5 'helemaal eens'. De scores op sommige items werden omgekeerd zodat een hoge score overeenkwam met veel self-efficacy bij het solliciteren $(M=3.36, S D=.45)$. Cronbach's $\alpha$ bedroeg .82 (Bijlage B).

Prestatiemotivatie: Voor deze schaal werd gebruikgemaakt van de vragenlijst Prestatie Motivatie Test van Hermans (1970). In totaal werden twaalf vragen gesteld. Per vraag varieerde het aantal antwoordmogelijkheden van twee tot vier antwoorden. De score werd berekend door gebruik te maken van een omzettingstabel. Een hoge score betekende een sterke prestatiemotivatie $(M=.56, S D=.14)$. Cronbach's $\alpha$ was .80 .

Positieve faalangst: Voor deze schaal is eveneens gebruikgemaakt van de vragenlijst Prestatie Motivatie Test van Hermans (1970). In totaal werden hiervoor 42 vragen gesteld. Per vraag varieerde het aantal antwoordmogelijkheden van twee tot vier antwoorden. De score werd berekend door gebruik te maken van een omzettingstabel. Een hoge score betekende dat men beter gaat functioneren dan waar onder normale omstandigheden sprake van is $(M=.65, S D=.20)$. Cronbach's $\alpha=.79$.

Baanstatus: Voor deze vraag werd gebruikgemaakt van de gegevens uit een cliëntenvolgsysteem om te bepalen welke werknemers na aanvang van het outplacementtraject na vier maanden een baan hadden en welke niet. Dit item werd gemeten als dichotome variabele: geen baan $=0$, wel een baan $=1$. In totaal vonden 44 van de 134 werknemers (=32.8\%) een baan (39 mannen en 5 vrouwen).

\section{Resultaten}

Correlaties tussen leeftijd, geslacht, opleiding, baanstatus, emotionele stabiliteit, extraversie, locus of control, professionele zelfverzekerdheid, sollicitatie-selfefficacy, prestatiemotivatie, positieve faalangst en uitstelgedrag zijn weergegeven in tabel 1. Significante verbanden met uitstelgedrag werden gevonden voor emotionele stabiliteit $(r=-.44)$, extraversie $(r=-.41)$, locus of control $(r=-.54)$, prestatiemotivatie $(r=-.38)$ en positieve faalangst $(r=-.22)$. Naarmate men zich emotioneel minder stabiel voelt, minder extravert is, minder tot prestaties te motiveren is en minder positieve faalangst ervaart, vertoont men meer uitstel- 
Tabel 1 Correlaties tussen de variabelen

\begin{tabular}{|c|c|c|c|c|c|c|c|c|c|c|c|c|}
\hline & $I$ & 2 & 3 & 4 & 5 & 6 & 7 & 8 & 9 & 10 & II & 12 \\
\hline \multicolumn{13}{|l|}{ I Uitstelgedrag } \\
\hline 2 Geslacht & -.10 & & & & & & & & & & & \\
\hline 3 Leeftijd & .00 & -.17 & & & & & & & & & & \\
\hline 4 Opleiding mbo & -.08 & .16 & -.01 & & & & & & & & & \\
\hline $\begin{array}{l}5 \text { Opleiding } \\
\text { hbo/wo }\end{array}$ & -.12 & -.09 & -.11 & $-.62 * *$ & & & & & & & & \\
\hline 6 Baanstatus & .08 & -.14 & $-.29 * *$ & -.02 & -.10 & & & & & & & \\
\hline $\begin{array}{l}7 \text { Emotionele stabi- } \\
\text { liteit }\end{array}$ & $-.44^{* *}$ & -.11 & -.04 & -.11 & .12 & .03 & & & & & & \\
\hline 8 Extraversie & $-.4 I^{* *}$ & -.03 & -.13 & -.05 & .02 & .17 & $.6 I^{* *}$ & & & & & \\
\hline 9 Locus of control & $-.54 * *$ & -.07 & -.07 & $-.21^{*}$ & .16 & .07 & $.67^{* *}$ & $.64^{* *}$ & & & & \\
\hline $\begin{array}{l}10 \text { Prof. zelf- } \\
\text { verzekerdheid }\end{array}$ & -.15 & $-.24 * *$ & .09 & $-.20 *$ & -.01 & .01 & $.32 * *$ & $.35^{* *}$ & $.44^{* *}$ & & & \\
\hline II Soll. self-efficacy & -.17 & -.11 & $-.23 * *$ & $-.27 * *$ & .12 & $.20^{*}$ & $.53^{* *}$ & $.48^{* *}$ & $.67^{* *}$ & $.53^{* *}$ & & \\
\hline $\begin{array}{l}12 \text { Prestatiemotiva- } \\
\text { tie }\end{array}$ & $-.38^{* *}$ & -.17 & -.04 & -.04 & -.03 & .00 & $.22 *$ & $.38^{* *}$ & $.4 I^{* *}$ & $.33^{* *}$ & $.28 * *$ & \\
\hline $\begin{array}{l}\text { I3 Positieve faal- } \\
\text { angst }\end{array}$ & $-.22^{*}$ & $-.29 * *$ & -.01 & -.12 & .07 & -.01 & $.48^{* *}$ & $.36^{* *}$ & $.47^{* *}$ & $.44^{* *}$ & $.44 * *$ & $.35^{* *}$ \\
\hline
\end{tabular}

Vanwege het missen van incidentele waarden varieert $N$ tussen I 20 en I34.

$* p<.05$ (tweezijdig); ** $p<.01$ (tweezijdig)

gedrag. Ook mensen met een externe locus of control stellen meer uit. Voor het wel of niet vinden van een andere baan werden significante verbanden gevonden voor leeftijd ( $r=-.29$ ) en sollicitatie-self-efficacy $(r=.20)$. Jongere werknemers hadden na vier maanden vaker een andere baan dan oudere, en respondenten met meer sollicitatie-self-efficacy hadden eveneens vaker een baan.

Om antwoord te krijgen op de vraag welke factoren in een outplacementsituatie samenhangen met uitstelgedrag, werd een hiërarchische regressieanalyse uitgevoerd met in blok 1 de controlevariabelen geslacht, leeftijd, opleiding, emotionele stabiliteit en extraversie als onafhankelijke variabelen en uitstelgedrag als afhankelijke variabele. In blok 2 werden als additionele onafhankelijke variabelen opgenomen: locus of control, prestatiemotivatie en positieve faalangst. In tabel 2 staan de resultaten van deze analyse vermeld. Omdat er geen samenhang was tussen professionele zelfverzekerdheid en uitstelgedrag en sollicitatie-self-efficacy en uitstelgedrag, werden deze variabelen niet meegenomen in de regressie-analyse. Voorafgaande aan deze analyse werden analyses uitgevoerd om assumpties van normaliteit, lineariteit, multicollineariteit en homoscedasticity na te gaan. Deze zijn geen van alle geschonden.

Uit de analyse blijkt dat het eerste model met de controlevariabelen significant was $(F(6,110)=7.97, p<.00)$. In stap 1 verklaren geslacht, leeftijd, opleiding, emotionele stabiliteit en extraversie in totaal $30 \%$ van de variantie. In dit model 
Tabel 2 Hiërarchische regressieanalyse met uitstelgedrag als afhankelijke variabele

\begin{tabular}{|c|c|c|c|c|c|c|c|c|}
\hline & \multicolumn{4}{|c|}{ Model I } & \multicolumn{4}{|c|}{ Model 2} \\
\hline & B & $S E$ & $\beta$ & $t$ & B & $S E$ & $\beta$ & $t$ \\
\hline \multicolumn{9}{|l|}{ Blok I } \\
\hline Geslacht & -.19 & .12 & -.14 & -1.67 & $-.22 *$ & .11 & $-.16 *$ & -2.03 \\
\hline Leeftijd & -.01 & .01 & -.10 & -1.25 & -.01 & .01 & -.11 & -1.48 \\
\hline \multicolumn{9}{|l|}{ Opleiding Ibo (ref.cat.) } \\
\hline Opleiding mbo & $-.30^{*}$ & .12 & $-.27 *$ & -2.58 & $-.37 * * *$ & .11 & $-.33 * * *$ & -3.48 \\
\hline Opleiding hbo/wo & $-.29 *$ & .12 & $-.26 *$ & -2.53 & $-.30 * *$ & .10 & $-.27 * *$ & -2.93 \\
\hline Emotionele stabiliteit & $-.28 * *$ & .10 & $-.30 * *$ & -2.92 & -.15 & .10 & .16 & -1.53 \\
\hline Extraversie & $-.3 I^{*}$ & .12 & $-.26 *$ & -2.55 & -.03 & .12 & .02 & -.23 \\
\hline \multicolumn{9}{|l|}{ Blok 2} \\
\hline Locus of control & & & & & $-.50 * * *$ & .14 & $-.39 * * *$ & -3.43 \\
\hline Prestatiemotivatie & & & & & $1.00 * *$ & .33 & $-.25 * *$ & -3.03 \\
\hline Positieve faalangst & & & & & .20 & .24 & .07 & .82 \\
\hline$N$ & \multicolumn{4}{|c|}{134} & \multicolumn{4}{|c|}{134} \\
\hline$R^{2}$ & \multicolumn{4}{|c|}{$30 \%$} & \multicolumn{4}{|c|}{$45 \%$} \\
\hline
\end{tabular}

$p<.01 ; * * p<.01 ; * * * p<.001$

waren opleiding (respectievelijk $\beta=-.27, p<.05$ en $\beta=-.26 p<.05$ voor de twee dummyvariabelen), emotionele stabiliteit $(\beta=-.30, p<.01)$ en extraversie $(\beta=-.26, p<.05)$ significante voorspellers van uitstelgedrag. In het tweede model werden bovenop de controlevariabelen de variabelen locus of control, prestatiemotivatie en positieve faalangst aan het model toegevoegd. Dit model was eveneens significant $(F(3,107)=9.45, p<.00)$. Er werden significante effecten gevonden voor geslacht $(\beta=-.16, p<.05)$, opleiding (respectievelijk $\beta=-.33, p<.001$ en $\beta=-.27, p<.01)$, locus of control $(\beta=-.39, p<.001)$ en prestatiemotivatie $(\beta=-.25, p<.01)$. Naarmate werknemers hoger waren opgeleid en meer gemotiveerd waren om prestaties te leveren, vertoonden zij minder uitstelgedrag. Respondenten met een interne locus of control vertoonden eveneens minder uitstelgedrag. De significante effecten van opleiding op uitstelgedrag bleven in dit model van kracht in tegenstelling tot de effecten van emotionele stabiliteit en extraversie. Model 2 verklaarde 15\% van de variantie bovenop de variantie van model 1 . De verklaarde variantie van het volledige model bedroeg $45 \%$. Vergeleken met soortgelijke onderzoeken is dat hoog.

Om na te gaan of er ook een relatie was tussen de verschillende variabelen, uitstelgedrag en het wel of niet vinden van een andere baan, werd een logistische regressie-analyse uitgevoerd met baanstatus als afhankelijke variabele en de overige variabelen als predictoren (tabel 3 ). Het volledige model voorspelde significant het vinden van een baan, $2(12, N=110)=27.32, p<.01$. Het model als geheel verklaarde tussen .22\% (Cox and Snell R square) en .30\% (Nagelkerke R squared) van de variantie van baanstatus en classificeerde $71.8 \%$ van de gevallen 
Tabel 3 Logistische regressieanalyse van de variabelen die baanstatus kunnen voorspellen

\begin{tabular}{|c|c|c|c|c|c|c|c|}
\hline & \multirow[b]{2}{*}{ B } & \multirow[b]{2}{*}{$S E$} & \multirow[b]{2}{*}{ Wald } & \multicolumn{4}{|c|}{ 95\% Cl Odds Ratio } \\
\hline & & & & df Sig & Lower & Odds $R$ & Upper \\
\hline Constant & -2.19 & 4.54 & .23 & 1.63 & & .11 & \\
\hline Leeftijd & -.10 & .04 & 6.86 & 1.01 & .84 & .91 & .98 \\
\hline Geslacht & 1.76 & .76 & 5.34 & 1.02 & 1.31 & 5.82 & 25.94 \\
\hline Opleiding (mbo) & .97 & .73 & 1.75 & 1.19 & .63 & 2.63 & 11.05 \\
\hline Opleiding (hbo/wo) & 1.47 & .68 & 4.63 & 1.03 & 1.14 & 4.36 & 16.65 \\
\hline Uitstelgedrag & -.10 & .63 & .02 & $1 \quad .88$ & .26 & .91 & 3.14 \\
\hline Emotionele stabiliteit & -.67 & .61 & 1.22 & I . .27 & .16 & .51 & 1.68 \\
\hline Extraversie & 1.43 & .76 & 3.55 & 1.06 & .94 & 4.17 & 18.44 \\
\hline Locus of control & -.02 & 1.10 & .00 & 1.99 & .12 & .98 & 8.42 \\
\hline Professionele zelfverzekerdheid & -.94 & .56 & 2.87 & I . .09 & .13 & .39 & 1.16 \\
\hline Sollicitatie-self-efficacy & 1.87 & .95 & 3.92 & I . .05 & 1.02 & 6.49 & 41.37 \\
\hline Prestatiemotivatie & -2.21 & 2.00 & 1.22 & I . .27 & .00 & .11 & 5.55 \\
\hline Positieve faalangst & -1.16 & 1.47 & .62 & 1.43 & .02 & .31 & 5.59 \\
\hline
\end{tabular}

correct. Uit de resultaten blijkt dat er geen significante verschillen zijn gevonden tussen werknemers die uitstelgedrag vertoonden en zij die geen uitstelgedrag vertoonden bij het vinden van een andere baan. Baanstatus wordt wel voorspeld door leeftijd, geslacht en sollicitatie-self-efficacy. Jongere en mannelijke werknemers vonden vaker een baan dan oudere en vrouwelijke werknemers, en zij die meer vertrouwen hebben in de eigen sollicitatievaardigheden, vonden vaker een baan dan werknemers die hierin minder vertrouwen hebben.

Uit de resultaten blijkt geen significante relatie tussen uitstelgedrag en het vinden van een andere baan en ook geen relatie tussen de verschillende variabelen en baanstatus (met uitzondering van sollicitatie-self-efficacy). De hypothese waarin verondersteld werd dat uitstelgedrag de relatie tussen de verschillende variabelen en het vinden van een baan medieerde, werd niet bevestigd. Uitstelgedrag medieerde de relatie tussen de verschillende variabelen en baanstatus niet.

\section{Discussie}

\subsection{De belangrijkste bevindingen}

In deze studie onderzochten we de relatie tussen locus of control, professionele zelfverzekerdheid, sollicitatie-self-efficacy, prestatiemotivatie, positieve faalangst en uitstelgedrag bij 134 Nederlandse werknemers in een outplacementsituatie. De verkregen resultaten vormen een uitbreiding van onze kennis over en inzichten in processen die een rol spelen bij uitstelgedrag bij werknemers die door verlies van hun baan moeten solliciteren. Door de veranderingen op de arbeidsmarkt gedurende de afgelopen decennia, onder andere de toename van het aantal met 
gedwongen ontslag geconfronteerde werknemers en de flexibilisering van de arbeidsmarkt, wordt van werknemers verwacht dat zij vaker dan voorheen (moeten) solliciteren. Dit is een proces dat echter voor lang niet iedereen eenvoudig is en bijgevolg kan leiden tot het uitstellen van sollicitatie-activiteiten. Het doel van deze studie was ten eerste te onderzoeken welke verbanden er bestaan tussen uitstelgedrag en verschillende persoonskenmerken van mensen in een outplacementsituatie, en ten tweede of en welke relatie er bestaat tussen uitstelgedrag en deze kenmerken en het vinden van een baan (figuur 1 ).

Uit de resultaten blijkt dat er een positief verband bestaat tussen locus of control en uitstelgedrag, wat een bevestiging is van hypothese 1. Personen met een externe locus of control stellen vaker uit. Deze bevinding is in lijn met de gedachte dat uitstelgedrag gezien wordt als het onvermogen tot zelfregulering. Mensen met een interne locus of control zijn zich bewust van het feit dat het achterwege laten van noodzakelijke acties om een doel te bereiken tot uitstelgedrag leidt. Zij overzien de consequenties van hun handelen meer dan zij die hun leven laten afhangen van het lot en geluk, wat een meer passieve houding impliceert en dus tot uitstelgedrag kan leiden. Het gevoel geen controle te hebben over hun omgeving kan bij mensen met een externe locus of control tot angst om te falen leiden en daardoor uitstelgedrag tot gevolg hebben.

Professionele zelfverzekerdheid en sollicitatie-self-efficacy blijken in ons onderzoek niet samen te hangen met uitstelgedrag. Hypothese $2 \mathrm{a}$ en hypothese $2 \mathrm{~b}$ worden daarmee niet bevestigd. Uit de logistische regressie-analyse blijkt echter wel dat werknemers met meer sollicitatie-self-efficacy vaker een baan vinden dan zij die minder vertrouwen hebben in hun sollicitatievaardigheden. Wanberg, Kanfer en Rotundo (1999) onderzochten de relatie tussen sollicitatie-self-efficacy en de intensiteit van het zoeken naar werk en vonden een significante relatie. Naarmate men meer vertrouwen in de eigen vaardigheden had, zocht men intensiever naar werk en vond men ook eerder werk. Een interessante bevinding uit dit onderzoek was dat de motivatie om naar werk te (blijven) zoeken bij werknemers die na drie maanden nog werkloos waren, als enige variabele de intensiteit van het zoeken significant voorspelde. Mensen die meer gemotiveerd waren, zochten ook na een periode van drie maanden intensiever naar werk dan mensen die minder gemotiveerd waren. Voor sollicitatie-self-efficacy werd geen effect gevonden. Wij veronderstellen op basis van deze resultaten dat zelf-regulerende vaardigheden, bijvoorbeeld het stellen van doelen, plannen en trainen van cognitieve vaardigheden om gemotiveerd te blijven voor het solliciteren, mogelijk belangrijker zijn dan het versterken van de sollicitatievaardigheden.

In de praktijk komen loopbaanadviseurs echter regelmatig tegen dat mensen die moeite hebben met het solliciteren, uitstelgedrag vertonen. Een reden waarom we in ons onderzoek geen relatie vonden tussen sollicitatie-self-efficacy en uitstelgedrag, kan ermee te maken hebben dat wij uitstelgedrag in het algemeen hebben onderzocht. Uit een theoretische analyse en review van Azjen en Fishbein (1977) blijkt dat er meer samenhang in onderzoeksresultaten wordt gevonden als er specifieke attitudes gemeten worden in relatie tot het specifieke gedrag dat men wil onderzoeken. Wellicht dat het door ons verwachte effect wel wordt gevonden als 
in een volgende studie uitstelgedrag met betrekking tot het solliciteren onderzocht wordt en niet uitstelgedrag in het algemeen.

Een andere bevinding uit onze studie is de significante relatie tussen prestatiemotivatie en uitstelgedrag, in tegenstelling tot de niet-significante relatie tussen positieve faalangst en het gedrag, wat een gedeeltelijke bevestiging van hypothese 3 is. Een verklaring waarom we geen verband aantroffen tussen positieve faalangst en uitstelgedrag, kan zijn dat het effect van positieve faalangst in de regressieanalyse is verdwenen doordat prestatiemotivatie en positieve faalangst sterk gecorreleerd zijn.

In tegenstelling tot onze verwachting hebben wij geen verschil gevonden tussen uitstelgedrag en het vinden van een andere baan (hypothese $4 \mathrm{a}$ ). Dit resultaat kan te maken hebben met de wijze waarop baanstatus in ons onderzoek geoperationaliseerd was. Mogelijk worden er wel effecten gevonden als preciezer onderzocht wordt op welke termijn men ander werk vindt. In een volgend onderzoek kan dit worden uitgedrukt in de tijd tussen de start van het outplacementtraject en het moment dat de arbeidsovereenkomst ondertekend wordt. Een andere mogelijkheid is mensen langer dan de in ons onderzoek gebruikte periode van vier maanden te volgen, bijvoorbeeld over een tijdsperiode van een jaar. Voor de hypothese waarin verondersteld werd dat de verschillende variabelen samenhangen met het vinden van een andere baan (hypothese $4 \mathrm{~b}$ ), werd alleen een significante relatie gevonden voor sollicitatie-self-efficacy. Kennelijk speelt het vertrouwen in de eigen sollicitatievaardigheden dus een belangrijke rol om het sollicitatieproces goed te kunnen doorlopen.

Voor de mediatiehypothese tussen uitstelgedrag, verschillende variabelen en het vinden van een baan is eveneens geen ondersteuning gevonden (hypothese 4c). Hiervoor zijn verschillende verklaringen mogelijk, bijvoorbeeld dat andere factoren een rol spelen zoals de situatie op de arbeidsmarkt, de financiële positie of de gezinssituatie. Een tekort aan specifieke vakkrachten in bepaalde beroepsgroepen vergroot de kans om op korte termijn werk te vinden, ook al heeft men de neiging sollicitatie-activiteiten uit te stellen. Een andere reden waarom wij geen verschil hebben gevonden, kan te maken hebben met de relatief kleine onderzoeksgroep. Wellicht dat bij grotere aantallen respondenten de relatie tussen uitstelgedrag en het wel of niet vinden van een andere baan meer zichtbaar wordt.

Ook de korte periode die wij als meetpunt hebben genomen (vier maanden), kan een verklaring zijn waarom wij geen mediatie vonden. Enerzijds leidt op dit moment de situatie op de arbeidsmarkt ertoe dat er minder banen beschikbaar zijn en de werkloosheid nog steeds oploopt. Bovendien lijken organisaties, omdat er voor veel functies voldoende geschikte kandidaten beschikbaar zijn, meer tijd en ruimte te nemen om de juiste kandidaat te selecteren. Procedures duren vaak langer dan voorheen, waardoor de kans om in een (korte) periode van vier maanden werk te vinden kleiner is dan een aantal jaren geleden. Het aantal respondenten dat binnen de onderzoeksperiode nog geen baan had, was daardoor wellicht relatief hoog. Anderzijds kan het zo zijn dat werknemers onder druk van de huidige situatie op de arbeidsmarkt de noodzaak voelen om het solliciteren niet uit te stellen, hoewel ze wel last kunnen hebben van uitstelgedrag. Een dergelijke verklaring wordt ook gegeven door Van Hooft, Born, Taris, Van der Flier en Blonk 
(2005). Zij onderzochten over een langere periode de mediërende rol van uitstelgedrag op de relatie tussen implementatie-intenties en gedrag om werk te gaan zoeken, maar vonden eveneens geen effecten.

Opvallend in ons onderzoek zijn de significante effecten voor opleidingsniveau. Hoger opgeleiden stellen minder vaak uit dan lager opgeleiden. Deze resultaten komen niet overeen met onderzoek van Hammer en Ferrari (2002) naar het voorkomen van verschillende vormen van uitstelgedrag tussen ongeschoolde werknemers en professionals. Volgens de auteurs ervaren ongeschoolde werknemers meer baanonzekerheid dan geschoolde en stellen zij daarom minder uit. In onze onderzoeksgroep hebben wij echter te maken met werknemers die allen hun baan verloren. Een simpele uitspraak over de gevonden verschillen is derhalve niet eenvoudig te geven. Wellicht dat lager opgeleiden meer moeite hebben te voldoen aan de eisen die tegenwoordig worden gesteld aan het solliciteren, al is het alleen maar omdat ze vaak minder computervaardigheden hebben en doorgaans minder toegang hebben tot het internet, vandaag de dag een voorwaarde om bij geschikte vacatures uit te komen. Het is de moeite waard om nader onderzoek te doen naar een verklaring voor de gevonden verschillen.

\subsection{Beperkingen}

Dit onderzoek kent een aantal beperkingen. Ten eerste gaat het in dit onderzoek om cross-sectioneel onderzoek, zodat voorzichtigheid op zijn plaats is waar het gaat om het leggen van causale relaties. Een tweede beperking is de generaliseerbaarheid van de onderzoeksresultaten naar werknemers in individuele outplacementsituaties. Er zijn alleen werknemers benaderd die in grotere aantallen tegelijkertijd hun baan verloren. Een derde beperking is de relatief korte termijn van vier maanden en de operationalisatie van de baanstatus die als uitgangspunt diende voor de vraag of uitstelgedrag leidt tot het wel of niet vinden van een baan. Wij gingen hier eerder al op in. Mogelijk worden verschillen meer zichtbaar als werknemers gevolgd worden gedurende een langere periode dan vier maanden waarin zij op zoek zijn naar ander werk. Het vinden van een baan kan dan worden meegenomen als kwantitatieve variabele. Bij de operationalisatie kan dan specifieker worden aangegeven hoeveel dagen een werkzoekende erover doet een baan te vinden in plaats van enkel een dichotome variabele te meten of iemand wel of geen baan heeft gevonden. In een volgend onderzoek kan dit nader worden onderzocht, waarbij bijvoorbeeld de start van het outplacementtraject als begindatum wordt genomen en de datum van de ondertekening van de arbeidsovereenkomst als einddatum. Tot slot heeft wellicht de relatief hoge leeftijd van de onderzoeksgroep een rol gespeeld. Het is algemeen bekend dat oudere werknemers er op dit moment langer over doen om werk te vinden dan jongere. Het kan interessant zijn om in een volgende studie verschillende leeftijdscohorten te vergelijken en te onderzoeken of binnen deze groepen uitstelgedrag wel van invloed is op het vinden van een nieuwe baan.

Samengevat kunnen we concluderen dat uitstelgedrag een probleem is dat niet alleen bij studenten voorkomt, maar ook bij werknemers in een outplacementsituatie. De gevonden resultaten betreffen echter met name de effecten van locus of control en prestatiemotivatie op uitstelgedrag en niet die van sollicitatie-self- 
efficacy. Uit ons onderzoek bleek sollicitatie-self-efficacy de enige niet-demografische variabele te zijn die van invloed is op het vinden van een baan. Voor loopbaanprofessionals die outplacementkandidaten begeleiden, zijn dit interessante bevindingen. Enerzijds zijn er mensen die last hebben van uitstelgedrag, maar bij wie dat niet van invloed is op het vinden van ander werk, anderzijds vinden mensen met meer vertrouwen in hun sollicitatievaardigheden vaker een baan dan mensen die hier minder vertrouwen in hebben.

De resultaten van ons onderzoek laten zien dat uitstelgedrag voorkomt bij werknemers in outplacementsituaties. Uitstelgedrag kost geld en kan ten koste gaan van de productiviteit en de gezondheid van mensen (Steel, 2011). Loopbaanprofessionals kunnen zichzelf bekwamen het gedrag te leren herkennen, bespreekbaar te maken en op het individu toegepaste interventies in te zetten, zodat men deze vaardigheden ook kan meenemen in een nieuwe functie. Wij verwachten bovendien dat in de toekomst de aandacht in outplacementtrajecten vaker uitgaat naar bijvoorbeeld het versterken van de (interne) locus of control, de prestatiemotivatie, de sollicitatie-self-efficacy en de zelfregulering. Waarschijnlijk wordt het bijbrengen van de meer praktische vaardigheden, zoals het opstellen van een brief of een $C V$, van meer secundair belang.

\section{Praktijkbox}

Wat betekenen de resultaten van het onderzoek voor de praktijk?

- Het bij aanvang van een outplacementtraject achterhalen of iemand last heeft van uitstelgedrag en welke problemen hieraan ten grondslag liggen, kan professionals helpen adequate begeleiding in te zetten.

- Het versterken van iemands gevoel van controle over situaties kan helpen uitstelgedrag te voorkomen.

- Uitstelgedrag kan worden verminderd door langetermijndoelen op te delen in kleinere doelen (Lowman, 1993).

- Uitstelgedrag kan worden voorkomen door implementatie-intenties te stellen (Owens, Bowman \& Dill, 2008). Dit betekent dat naast het opstellen van doelen ook vastgelegd wordt wanneer bepaalde activiteiten ondernomen worden, hoe deze worden aangepakt en op welke wijze de evaluatie plaatsvindt. Het is belangrijk om stil te staan bij (kleine) successen en welke stappen hiertoe hebben bijgedragen.

- Ook het snel helder krijgen van de mate waarin men vertrouwen heeft in de eigen sollicitatievaardigheden, kan ertoe bijdragen een op het individu toegepast begeleidingstraject in te zetten.

- Professionals kunnen interventies ontwikkelen en toepassen in de zoektocht naar werk om de motivatie en de copingvaardigheden te versterken, en interventies ontwikkelen om de motivatie ook vol te houden (Vinokur, Price \& Schul, 1995; Wanberg et al., 1999). 


\section{Literatuur}

Azjen, I. \& Fishbein, M. (1977). Attitude-behavior relations: A theoretical analysis and review of empirical research. Psychological Bulletin, 84, 888-918.

Bandura, A. (1977). Self-efficacy: Toward a unifying theory of behavioral change. Psychological Review, 84, 191-215.

Baron, R.M. \& Kenny, D.A. (1986). The moderator-mediator variable distinction in social psychological research: Conceptual, strategic, and statistical considerations. Journal of Personality and Social Psychology, 51, 1173-1182.

Baumeister, R.F. \& Heatherthon, T.F. (1996). Self-regulation failure: An overview. Psychological Inquiry, 7, 1-15.

Burka, J.B. \& Yuen, L.M. (1983). Procrastination: Why you do it, what to do about it. Reading, MA: Addison-Wesley.

Carver, C.S. \& Scheier, M.F. (2000). On the structure of behavioral self-regulation. In M. Boekaerts, P.R. Pintrich \& M. Zeidner (Eds.), Handbook of self-regulation (pp. 41-84). San Diego, CA: Academic Press.

Caska, B.A. (1998). The search for employment: Motivation to engage in a coping behavior. Journal of Applied Social Psychology, 28, 206-224.

CBS (2012). http://www.cbs.nl/nl-NL/menu/themas/arbeid-sociale-zekerheid/publicaties/ artikelen/archief/2013/2012-werkloosheid-2012-art.htm

CBS (2013a): http://www.cbs.nl/nl-NL/menu/themas/arbeid-sociale-zekerheid/ publicaties/ artikelen/archief/2012/2012-003-pb.htm

CBS (2013b): http://www.cbs.nl/nl-NL/menu/themas/arbeid-sociale-zekerheid/ publicaties/ artikelen/archief/2013/2013-026-pb.htm

Cole, K. (2006). Wellbeing, psychological capital, and unemployment: An integrated theory. www.melbourneinstitute.com/downloads/hilda/Bibliography/Conference_ Papers/Paris\%20Paper\%2020061.pdf.

Construct. (2009). Impuls en drijfverenscan. Amsterdam: Construct Bedrijfspsychologie.

De Witte, H., Van Hoof, J. \& Vos, K. (2007). Baanonzekerheid, werknemersreacties en vakbondsparticipatie. Tijdschrift voor Arbeidsvraagstukken, 23, 89-91.

Ferrari, J.R., Johnson, L.J. \& McCown, W.G. (1995). Procrastination and task avoidance: Theory, research and treatment. New York: Plenum Press.

Goldberg, L.R., Johnson, J.A., Eber, H.W., Hogan, R., Ashton, M.C., Cloninger, C.R. \& Gough, H.G. (2006). The international personality item pool and the future of publicdomain personality measures. Journal of Research in Personality, 40, 84-96.

Grimes, P.W., Millea, M.J. \& Woodruff, T.W. (2004). Grades - who's to blame? Student evaluation of teaching and locus of control. The Journal of Economic Education, 35, 129-147.

Hammer, C.A. \& Ferrari, J.R. (2002). Differential incidence of procrastination between blue- and white-collar workers. Current Psychology, 21, 333-338.

Harriott, J. \& Ferrari, J.R. (1996). Prevalence of procrastination among samples of adults. Psychological Reports, 78, 611-616.

Hermans, H.J.M. (1970). A questionnaire measure of achievement motivation. Journal of Applied Psychology, 54, 353-363.

Hoekstra, H.A., Ormel, J. \& Fruyt, F. (2007). NEO-PI-R / NEO-FFI. Handleiding. Amsterdam: Hogrefe Uitgevers.

Houtman, I. \& Van den Bossche, S. (2010). Trends in de kwaliteit van de arbeid in Nederland en Europa. Tijdschrift voor Arbeidsvraagstukken, 26, 432-450.

International Personality Item Pool (IPIP). http://ipip.ori.org/newPASKey.htm 
Judge, T.A., Locke, E.A. \& Durham, C.C. (1997). The dispositional causes of job satisfaction: A core evaluations approach. Research in Organizational Behavior, 19, 151-188.

Kanfer, R., Wanberg, C.R. \& Krantowitz, T.M. (2001). Job search and employment: A personality-motivational analysis and meta-analytic review. Journal of Applied Psychology, $86,837-855$.

Knaus, B., Klarreich, S., Grieger, R. \& Knaus, N. (2010). Fearless jobhunting. Oakland: New Harbinger Publications.

Lay, C.H. (1986). At last, my research article on procrastination. Journal of Research in Personality, 20, 474-495.

Lay, C.H. \& Brokenshire, R. (1997). Conscientiousness, procrastination, and person-task characteristics in job searching by unemployed adults. Current Psychology, 16, 83-96.

Lowman, R.L. (1993). Counseling and psychotherapy of work dysfunctions. Washington, DC: American Psychological Association.

McClelland, D.C, Atkinson, J.W., Clark, R.A. \& Lowell, E.L. (1953). The achievement motive. New York: Appleton-Century-Crofts.

Miner, J.B. (2002). Organizational behaviour: Foundations, theories and analyses. New York, NY: Oxford University Press.

Ng, T.W.H., Sorensen, K.L. \& Eby, L.T. (2006). Locus of control at work: A meta-analysis. Journal of Organizational Behavior, 27, 1057-1087.

Owens, S.G., Bowman, C.G. \& Dill, C.A. (2008). Overcoming procrastination: The effect of implementation intentions. Journal of Applied Social Psychology, 38, 366-384.

Pychyl, T.A., Lee, J.M., Thibodeau, R. \& Blunt, A. (2000). Five days of emotions: An experience sampling study of undergraduate student procrastination. Journal of Social Behavior and Personality, 15, 239-254.

Rabideau, S.T. (2005). Effects of achievement motivation on behavior. www.personality research.org/papers/rabideau.html

Renn, R.W., Allen, D.G., Fedor, D.B. \& Davis, W.D. (2005). The roles of personality and self-defeating behaviors in self-management failure. Journal of Management, 31, 659-679.

Rothblum, E.D., Solomon, L.J. \& Murakami, J. (1986). Affective, cognitive, and behavioral differences between high and low procrastinators. Journal of Counseling Psychology, 33, 387-394.

Rotter, J.B. (1966). Generalized expectancies for internal versus external control of reinforcement. Psychological Monographs: General and Applied, 80, 1-28.

Saks, A.M. \& Ashforth, B.E. (1999). Effects of individual differences and job search behaviors on the employment status of recent university graduates. Journal of Vocational Behavior, 54, 335-349.

Senécal, C. \& Guay, F. (2000). Procrastination in job-seeking: An analysis of motivational processes and feelings of hopelessness. Journal of Social Behavior and Personality, 15, 267-282.

Steel, P. (2007). The nature of procrastination: A meta-analytic and theoretical review of quintessential self-regulatory failure. Psychological Bulletin, 133, 65-94.

Steel, P. (2010). Arousal, avoidant and decisional procrastinators: Do they exist? Personality and Individual Differences, 48, 926-934.

Steel, P. (2011). Uitstelgedrag [The procrastination equation]. Utrecht: Uitgeverij Ten Have.

Van Eerde, W. (2000). Procrastination: Self-regulation in initiating aversive goals. Applied Psychology: An International Review, 49, 372-389.

Van Eerde, W. (2003). A meta-analytically derived nomological network of procrastination. Personality and Individual Differences, 35, 1401-1418. 
Van Hooft, E.A.J., Born, M.Ph., Taris, T.W., Van der Flier, H. \& Blonk, R.W.B. (2005). Bridging the gap between intentions and behavior: Implementation intentions, action control, and procrastination. Journal of Vocational Behavior, 66, 238-256.

Van Hooft, E.A.J. \& Noordzij, G. (2009). The effects of goal orientation on job search and reemployment: A field experiment among unemployed job seekers. Journal of Applied Psychology, 94, 1581-1590.

Van Ryn, M. \& Vinokur, A.D. (1992). How did it work? An examination of the mechanisms through which an intervention for the unemployed promoted job search behavior. American Journal of Community Psychology, 20, 577-597.

Vinokur, A.D., Price, R.H. \& Schul, Y. (1995). Impact of the JOBS intervention on unemployed workers varying in risk factors for depression. American Journal of Community Psychology, 23, 39-74.

Vlasblom, J.D., Josten, E. \& De Voogd-Hamelink, M. (2013). Aanbod van arbeid 2012. Den Haag: Sociaal en Cultureel Planbureau.

Wanberg, C.R., Kanfer, R. \& Rotundo, M. (1999). Unemployed individuals: Motives, jobsearch competencies, and job-search constraints as predictors of job seeking and reemployment. Journal of Applied Psychology, 84, 897-910.

Wanberg, C.R., Zhu, J. \& Van Hooft, E.A.J. (2010). The job search grind: perceived progress, self-reactions, and self-regulation of search effort. Academy of Management Journal, 53, 788-807.

Watson, D.C. (2001). Procrastination and the five-factor model: A facet level analysis. Personality and Individual Differences, 30, 149-158.

Wohl, M.J.A., Pychyl, T.A. \& Bennet, S.H. (2010). I forgive myself, now I can study: How self-forgiveness for procrastinating can reduce future procrastination. Personality and Individual Differences, 48, 803-808.

Zikic, J. \& Saks, A.M. (2009). Job search and social cognitive theory: The role of careerrelevant activities. Journal of Vocational Behavior, 74, 117-127.

\section{Bijlage A: Professionele zelfverzekerdheid}

\section{Copyright/auteursrecht: Construct Bedrijfspsychologie Amsterdam}

1. Ik voel mij op mijn gemak in een discussie, over welk onderwerp dan ook.

2. Ik ben in staat een nieuwe aanpak en nieuwe procedures voor mijn werk te ontwerpen.

3. De meeste problemen en opdrachten kan ik aan.

4. Ik weet wat ik waard ben en twijfel weinig aan mezelf.

5. Ik zou goed kunnen bijdragen aan de samenwerking tussen mijn organisatie (bedrijf) en buitenstaanders zoals klanten, leveranciers, of managers.

6. Ik zou mij zelfverzekerd voelen als ik mijn werkgroep of afdeling moet vertegenwoordigen op een bijeenkomst met managers.

7. Ik zou goed een voorstel kunnen doen over waarin we moeten investeren in mijn organisatie of afdeling.

8. Ik zou mij zeker voelen wanneer ik aan mijn manager moest uitleggen hoe ik mijn werk doe. 


\section{Bijlage B: Sollicitatie-self-efficacy}

1. Ik weet niet hoe ik het solliciteren moet aanpakken.*

2. Hoe ik mijn enthousiasme voor een baan in een sollicitatiegesprek moet brengen is voor mij geen enkel probleem.

3. Ik durf alleen een nieuwe baan te accepteren als ik heel zeker weet dat deze bij mij past.*

4. Ik ben ervan overtuigd dat ik de baan krijg die ik ook hebben wil.

5. Solliciteren vind ik saai en oninteressant.*

6. Ik beschik over de vaardigheid een potentiële werkgever van mijn kwaliteiten te overtuigen.

7. Ik stel mij flexibel op bij het vinden van een andere baan.

8. Ik vind het moeilijk dat ik mezelf straks in sollicitatiegesprekken moet gaan bewijzen.*

9. Ik ben afhankelijk van de werkgever of ik wel of niet word aangenomen.*

10. Of ik ander werk vind heb ik zelf niet in de hand.*

11. Ik heb er vertrouwen in dat ik een andere baan vind, ongeacht hoe lang dit gaat duren.

12. Voor een toekomstige werkgever ben ik de moeite waard.

13. Het lukt mij vast niet op korte termijn een andere baan te vinden.*

14. Een nieuwe werkgever moet mij nemen zoals ik ben.

15. Mijn leeftijd ervaar ik als een belemmering bij het vinden van een andere baan.*

16. Solliciteren vind ik leuk om te doen.

17. Ik heb niet voldoende kwaliteiten in huis om een andere baan te vinden.*

18. Ik ben voldoende gekwalificeerd om snel een andere baan te vinden.

19. Ik mag van mezelf geen fouten maken in een sollicitatiegesprek.*

20. Het maakt mij onzeker dat bij het solliciteren niet bekend is wanneer ik een nieuwe baan vind.*

* Items omgekeerd $(1,3,5,8,9,10,13,15,17,19,20)$

\section{Procrastination in outplacement situations}

Monique V.E. Leenders \& Jua B.P. Sanders, Gedrag \& Organisatie, volume 27, March 2014, nr. 1, pp. 90-110.

In this study we investigated the relationship between several personality aspects and procrastination in an outplacement situation in which people have to apply for a job. A total of 134 employees from different organizations, who lost their job because of company closure or reorganization, filled out a questionnaire. The analyses showed that procrastination was more likely among those employees with an external locus of control and who had low levels of achievement motivation. After a four-month outplacement period, however, employees high on procrastination were not less successful in finding a job compared to those who pro- 
crastinated less. It is possible that other aspects play a role, for instance the demand for specific employers on the labor market.

Key words: procrastination, job loss, to apply, outplacement 